\title{
SPLIT-COURSE ACCELERATED HYPERFRACTIONATED RADIOTHERAPY IN HEAD AND NECK CARCINOMA- AN EXPERIENCE IN TERMS OF LOCAL TUMOUR CONTROL AND TOXICITY
}

\author{
Ramesh Arya ${ }^{1}$, Vinay Shivhare ${ }^{2}$, Preeti Jain ${ }^{3}$, Allwin George ${ }^{4}$, Love Goyal5, Minal Iyer $^{6}$, Vaibhav Saini ${ }^{7}$ \\ ${ }^{1}$ Associate Professor, Department of Radiation Oncology, Government Cancer Hospital, Indore. \\ ${ }^{2} 3^{\text {rd }}$ Year Junior Resident, Department of Radiation Oncology, Government Cancer Hospital, Indore. \\ ${ }^{3}$ Assistant Professor, Department of Radiation Oncology, Government Cancer Hospital, Indore. \\ $43^{\text {rd }}$ Year Junior Resident, Department of Radiation Oncology, Government Cancer Hospital, Indore. \\ ${ }^{5}$ Senior Resident, Department of Radiation Oncology, Government Cancer Hospital, Indore. \\ ${ }^{6} 2^{\text {nd }}$ Year Junior Resident, Department of Radiation Oncology, Government Cancer Hospital, Indore. \\ $72^{\text {nd }}$ Year Junior Resident, Department of Radiation Oncology, Government Cancer Hospital, Indore.
}

\section{ABSTRACT}

\section{BACKGROUND}

Radiotherapy alone was long the standard nonsurgical therapy for locally advanced disease. A recent meta-analysis of randomised trial testing modified fractionation schemes against conventional once-daily fractionation demonstrated that hyperfractionation was the most effective strategy, leading to an $8 \%$ absolute improvement in 5-year survival. Split-course technique has been used in head and neck cancer patients as an alternative to conventional fractionation. Current evidence shows that split-course radiotherapy is radiobiologically sound and produces similar results as conventional radiotherapy with less number of fractions and increased patient compliance. In our study, we would like to present the results of split-course radiotherapy in advanced head and neck cancer.

Aims and Objectives- To evaluate split-course accelerated hyperfractionated radiotherapy in aspects of Local Tumour Control and early and Late Radiation Toxicity.

\section{MATERIALS AND METHODS}

50 patients with squamous cell carcinoma of oral cavity, anterior $2 / 3^{\text {rd }}$ of tongue, Alveolus, Lip in stage III and IV have been treated in SGPT Cancer Hospital, MGM Medical College, Indore from Feb. 2013 to Feb. 2014. There were 18 patients with stage III and 32 patients with stage IV, all the patients were treated by radiation therapy alone. Using the technique of opposed parallel fields and split-course accelerated hyper-fractionation with similar dose per fraction and reduced boost volume during the second part of treatment schedule. The total dose was $64 \mathrm{~Gy}$. The median follow-up period was 16 months.

\section{RESULTS}

Grade III and IV acute toxicity was observed in $32 \%$ and $16 \%$ of the patients. At one and half years, complete response and partial response were $56 \%$ and $36 \%$ respectively and $8 \%$ patients with no response.

\section{CONCLUSION}

Patients unable to tolerate continuous-course definite (Chemo) Radiotherapy, split-course accelerated hyperfractionated radiotherapy is safe, well tolerated and effective method of achieving durable locoregional disease control.

\section{KEYWORDS}

Split-Course Radiotherapy, Head and Neck Cancers.

HOW TO CITE THIS ARTICLE: Arya R, Shivhare V, Jain P, et al. Split-course accelerated hyperfractionated radiotherapy in head and neck carcinoma- An experience in terms of local tumour control and toxicity. J. Evolution Med. Dent. Sci. 2017;6(42):32923296, DOI: $10.14260 /$ Jemds/2017/713

\section{BACKGROUND}

Worldwide, approximately 600,000 patients are afflicted with squamous cell head and neck cancer. Nearly $60 \%$ population present with locally advanced but non-metastatic disease.[1] Radiotherapy alone was long the standard nonsurgical therapy for locally advanced disease. Newer strategies of hyperfractionation and accelerated fractionation lead to $7 \%$

Financial or Other, Competing Interest: None.

Submission 13-04-2017, Peer Review 15-05-2017,

Acceptance 18-05-2017, Published 25-05-2017.

Corresponding Author:

Dr. Vinay Shivhare,

$3^{\text {rd }}$ Year Junior Resident,

Department of Radiation Oncology,

Government Cancer Hospital,

Indore.

E-mail: shivharevinay@yahoo.com

DOI: $10.14260 /$ jemds $/ 2017 / 713$

\section{(c) (i) $\odot$}

to $10 \%$ improvement in locoregional control compared to once-daily treatment schemes.[2,3,4,5,6] A recent meta-analysis of randomised trial testing modified fractionation schemes against conventional once-daily fractionation demonstrated that hyperfractionation was the most effective strategy, leading to an $8 \%$ absolute improvement in 5-year survival.[7,8,9,10]

Split-course radiotherapy is basically used in advanced cancer to differentiate between well responding tumours from poorly responding tumours in various regimen and intervals.[11,12,13] Previous studies the in past had tried splitcourse radiotherapy in lung cancer patients to differentiate between well responding tumours from poorly responding tumours.[12,13] Subsequently, split-course technique has been used in head and neck cancer patients as an alternative to conventional fractionation. Current evidence shows that splitcourse radiotherapy is radiobiologically sound and produces similar results as conventional radiotherapy with less 
number of fractions and increased patient compliance.[14,15,16,17,18,19] Here we would like to present our result of split-course radiotherapy in advanced head and neck cancer.

\section{MATERIALS AND METHODS}

From Feb. 2013 to Feb. 2014, 50 patients with advanced head and neck carcinoma at SGPT Cancer Hospital and MGM Medical College, Indore were treated with Radiotherapy by using the parallel opposed field technique with dose of $1.6 \mathrm{~Gy}$ per fraction, two fractions per day with minimum of 6-hour interval between fraction for duration of 12 days, 5 days a week, to a total dose of 38.4 Gy in 2.5 weeks. This was followed by a rest period of 14 days. Subsequently, treatment was resumed to deliver 1.6 Gy twice daily to a reduced boost volume encompassing the primary tumour and clinically positive nodes for additional dose of 28.8 Gy in 9 treatment days. The total dose to primary tumour and the positive nodes was $67.2 \mathrm{~Gy}$ in 42 fractions over 6 weeks. The prophylactic anterior lower neck field received total dose up to 50 Gy only.[20]

\begin{tabular}{|c|c|}
\hline Mean Age (Years) & 45 Years \\
\hline Male/ Female & $24(48 \%) / 26(52 \%)$ \\
\hline Urban/Rural & $22(44 \%) / 28(56 \%)$ \\
\hline \multicolumn{2}{|c|}{ Table 1. Patient's Characteristics } \\
\hline
\end{tabular}

\begin{tabular}{|c|c|}
\hline Symptoms & Number of Patients (Percent) \\
\hline Pain & $46(92 \%)$ \\
\hline Ulcer & $42(84 \%)$ \\
\hline Swelling & $42(84 \%)$ \\
\hline Excessive salivation & $06(12 \%)$ \\
\hline Trismus & $10(20 \%)$ \\
Fistula & $10(20 \%)$ \\
\hline \multicolumn{2}{|c|}{ Table 2. Symptoms at Presentation } \\
\hline
\end{tabular}

\begin{tabular}{|c|c|c|c|c|c|}
\hline No. & Age Group & Male & Female & Total & $\mathbf{\%}$ \\
\hline 1 & $31-40$ & 6 & 0 & 6 & 12 \\
\hline 2 & $41-50$ & 10 & 10 & 20 & 40 \\
\hline 3 & $51-60$ & 8 & 14 & 22 & 44 \\
\hline 4 & $61-70$ & 0 & 2 & 02 & 04 \\
\hline Total & $\mathbf{2 4}$ & $\mathbf{2 6}$ & $\mathbf{5 0}$ & $\mathbf{1 0 0}$ \\
\hline \multicolumn{7}{|c|}{ Table 3. Age Distribution } \\
\hline
\end{tabular}

\begin{tabular}{|c|c|c|c|c|}
\hline & Buccal Mucosa & Tongue & Alveolus & Lower-lip \\
\hline Stage & & & & \\
\hline III & 12 & 4 & 2 & 0 \\
IV & 10 & 4 & 12 & 6 \\
\hline Total & $\mathbf{2 2}$ & $\mathbf{8}$ & $\mathbf{1 4}$ & $\mathbf{6}$ \\
\hline \multicolumn{4}{|c|}{ Table 4. Staging \& Location of Tumour } \\
\hline
\end{tabular}

\begin{tabular}{|c|c|}
\hline Types & Number of Patients (Percent) \\
\hline Ulceroproliferative & $34(68 \%)$ \\
\hline Infiltrative & $16(32 \%)$ \\
\hline \multicolumn{2}{|c|}{ Table 5. Clinical Appearance of Growth } \\
\hline
\end{tabular}

\begin{tabular}{|c|c|}
\hline Types $^{*}$ & Number of Patients (Percent) \\
\hline Well differentiated & $12(24 \%)$ \\
\hline Moderately differentiated & $20(40 \%)$ \\
\hline Poorly differentiated & $02(04 \%)$ \\
\hline $\begin{array}{c}\text { Unclassified Squamous cell } \\
\text { carcinoma }\end{array}$ & $16(32 \%)$ \\
\hline \multicolumn{2}{|c|}{ Table 6. Histopathological Appearance of Growth } \\
\hline
\end{tabular}

*American Joint Committee on Cancer

\section{RESULTS}

The study was limited to subsets of patients with squamous cell carcinoma of buccal mucosa, alveolus, tongue and lip, treated with twice daily dose from Feb. 2013 up to Dec. 2013. Table 1 shows the distribution of lesions in these four groups of patients. The local control rate was comparable with the other study done with the same protocol by different authors. The results are shown in the table 5.

All the patients developed confluent mucositis during the radiation course, with the peak seen at the end of second and third week of radiotherapy, which required hospitalisation of patients for supportive care i.e. IV fluid, multivitamin, analgesic, antibiotic and local application of soothing gel, etc. After second and third week, there was continuous decrease in patients except fourth and fifth week where there was slight increase in the occurrence of mucositis patients. Grade III dysphagia was seen in $5^{\text {th }}$ and $6^{\text {th }}$ week after initiation of radiotherapy course. Tolerance of second part was better than the first one, mainly because of the partial healing of mucositis during the gap period.

For advanced Head and Neck $\mathrm{T}_{3}$ and $\mathrm{T}_{4}$ lesions, the local and regional control is extremely poor with 3-year diseasefree survival of approximately $25 \%$ to $30 \%$ and these lesions are currently managed in most centres by combined surgery and radiation therapy with or without chemotherapy. Many strategies and radiation technique with different outcomes are predicted with a hope to improve survival for advanced tumour. These are hyperbaric oxygen, hypoxic cell sensitisers, high and low linear energy transfer, particulate radiation i.e. proton, neutron, hyperthermia and various radiation fractionation including split-course radiation, most of which are in developmental phase.

\begin{tabular}{|c|c|c|c|c|}
\hline Sites & $\begin{array}{c}\text { No. of } \\
\text { Cases }\end{array}$ & $\begin{array}{c}\text { Complete } \\
\text { Response } \\
\text { n (\%) }\end{array}$ & $\begin{array}{c}\text { Partial } \\
\text { Response } \\
\text { n (\%) }\end{array}$ & $\begin{array}{c}\text { No } \\
\text { Response } \\
\text { n (\%) }\end{array}$ \\
\hline $\begin{array}{c}\text { Buccal } \\
\text { mucosa }\end{array}$ & 22 & $\begin{array}{c}16 \\
(72.72 \%)\end{array}$ & $\begin{array}{c}6 \\
(27.27 \%)\end{array}$ & $\begin{array}{c}0 \\
(0 \%)\end{array}$ \\
\hline $\begin{array}{c}\text { Gingio- } \\
\text { alveolus }\end{array}$ & 14 & $\begin{array}{c}08 \\
(57.14 \%)\end{array}$ & $\begin{array}{c}6 \\
(42.85 \%)\end{array}$ & $\begin{array}{c}0 \\
(0 \%)\end{array}$ \\
\hline Oral tongue & 08 & $\begin{array}{c}02 \\
(25 \%)\end{array}$ & $\begin{array}{c}04 \\
(50 \%)\end{array}$ & $\begin{array}{c}02 \\
(25 \%)\end{array}$ \\
\hline Lip & 06 & $\begin{array}{c}02 \\
(33.33 \%)\end{array}$ & $\begin{array}{c}02 \\
(33.33 \%)\end{array}$ & $\begin{array}{c}02 \\
(33.33 \%)\end{array}$ \\
\hline $\begin{array}{c}\text { Number } \\
\text { (percent) }\end{array}$ & 50 & $\begin{array}{c}28 \\
(56 \%)\end{array}$ & $\begin{array}{c}18 \\
(36 \%)\end{array}$ & $\begin{array}{c}04 \\
(08 \%)\end{array}$ \\
\hline \multicolumn{4}{|c|}{ Table 7. Subsite Analysis of Response } \\
\hline
\end{tabular}

* Response evaluation by RECIST Criteria

Pearson chi-square $=14.705, \mathrm{DF}=6$; The two tailed $\mathrm{P}$ value $=0.0227$ (Statistically significant). 


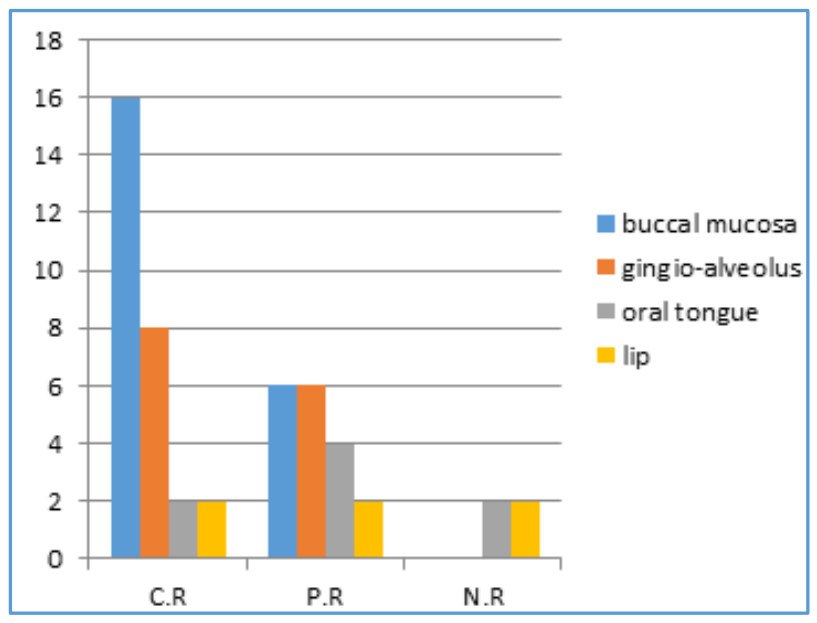

Figure I. Bar Diagram

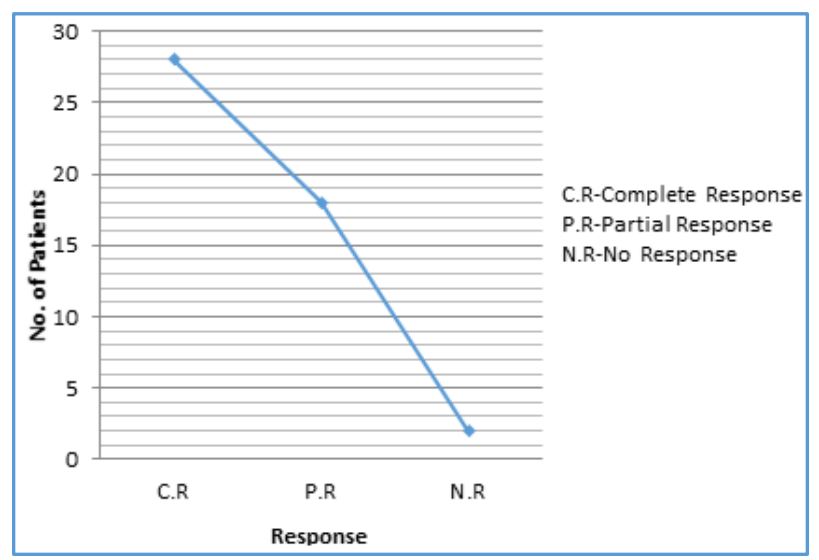

Figure II. Line Diagram of Subsets Analysis of Responses to Treatment Overall Responses to Treatment

\begin{tabular}{|c|c|c|}
\hline Grade $^{*}$ & No. of Patients & $\mathbf{\%}$ \\
\hline I & 06 & $12 \%$ \\
\hline II & 20 & $40 \%$ \\
\hline III & 16 & $32 \%$ \\
\hline IV & 08 & $16 \%$ \\
\hline \multicolumn{2}{|c|}{ Table 8. Occurrence of Mucositis } \\
\hline
\end{tabular}

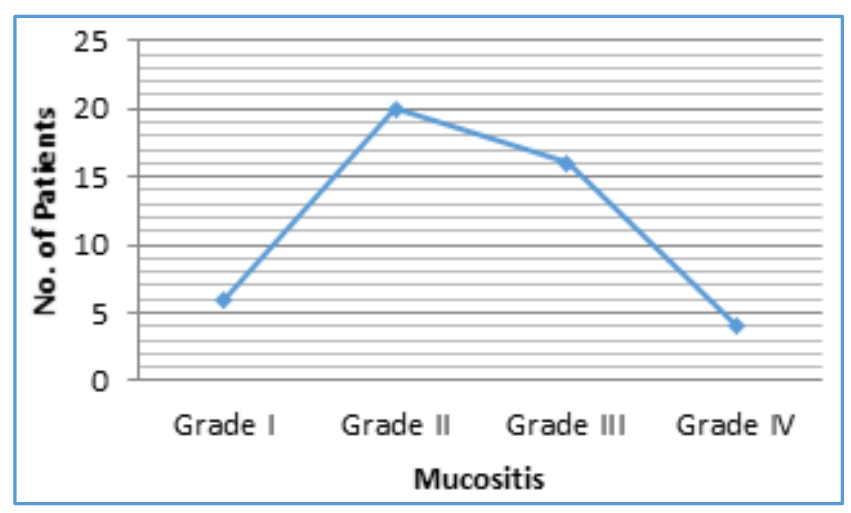

Figure 3. Line Diagram of Occurrence of Mucositis

\begin{tabular}{|c|c|}
\hline Grade I & 14 \\
\hline Grade II A & 10 \\
\hline Grade II B & 22 \\
\hline Grade III & 04 \\
\hline Grade IV & 00 \\
\hline Table 9. Occurrence of Skin Reaction \\
\hline
\end{tabular}

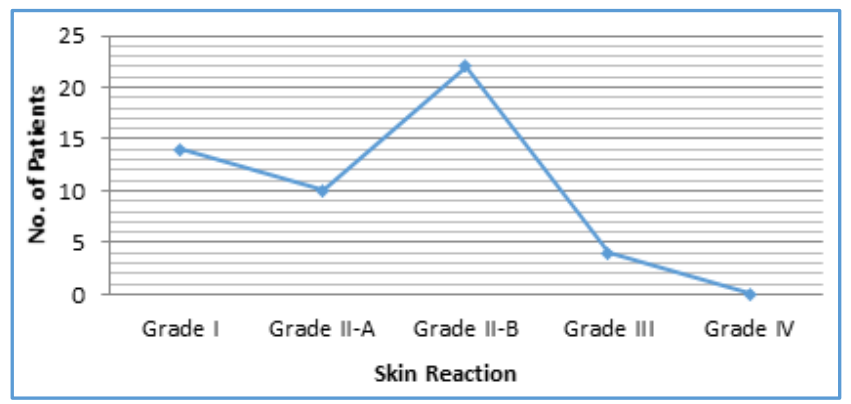

Figure 4. Line Diagram of Occurrence of Skin Reaction

Patients followed for 16 months, every 1-2 months during the first 6 months after completion of treatment, every 2-3 months in the next 6 months, every 3-4 months during second year. The visit 3 months after treatment is particularly important because at this time, the baseline result of treatment should be established. Besides detailed clinical assessment, a baseline imaging study is also advisable for all patients.

Each follow-up visit included careful history, detailed systemic and site-specific examination, CBC, RFT, LFT, and ultrasonography of neck. CECT neck was done in every patient in $1^{\text {st }}$ visit, subsequently CECT Neck was done only in symptomatic patients along with abovementioned investigation.

\section{DISCUSSION}

This study presents the outcome of 50 high risk advanced stage III \& IV head and neck cancer cases treated in our institute with split-course hyperfractionated external radiotherapy. Recovery of normal tissue noted during the resting period between two courses. Various types of fractionated regimens varying from hypofractionated to accelerated hyperfractionation and continuous accelerated hyperfractionation have been tried in clinical practice.

Thames et al (1983) reviewed the rationale behind the accelerated fractionation and discussed the result of some multiple-dose fraction in the form of accelerated and hyperfractionation.[21]

The two-week resting period after 38.4 Gy is necessary due to the maximal radiation reactions that can be tolerated by most patients and has not been found to be detrimental in tumour control in spite of probable tumour cell repopulation occurring during that period. Instead, the ability of the normal mucous membrane to regenerate rapidly after radiation damage during this rest period enables the completion of the remaining split-course radiation therapy, usually without further difficulty.

The per-fraction dose of 1.6 Gy chosen in the present study is more than 1.25 Gy (the likely upper limit of dose per fraction of a properly hyperfractionated regimen) and less than $1.8 \mathrm{~Gy}$, the lower limit of conventional dose per fraction (Klither H.R.)

A 6-hour interval between fractions on each day, as the interval is too short, the maximum repair of sublethal damage in normal tissue would not occur and as a result some of the benefits would be lost. This would be particularly important for late damage as a greater amount of recoverable injury occurs in late reacting tissue. In some clinical studies, 
accelerated fractionation has shown an increase in early and late radiation damage, their interval has been between 2 to 4 hours.[22] Majority of patients tolerated the radiation with grade II Mucositis 40\% (20/50) and grade III Mucositis 32\% $(16 / 50)$ while grade IV Mucositis was seen in $16 \%(8 / 50)$ and this Mucositis was seen on the $10^{\text {th }}$ day of the first phase and gets subsided rapidly during the two-week interval period and this again reaches to maximum at the completion of second phase, with severe pain/dysphagia, and patients required hospitalisation and supportive care. This mucositis subsided after 4-5 weeks of completion of radiation. Our acute mucositis results are comparable to $\mathrm{Fu} \mathrm{KK}$ et al[23] results which showed grade I mucositis in $16 \%$, grade II mucositis in $24 \%$ and grade III mucositis in $58 \%$ of patients, grade IV mucositis was not observed in any patients. Similarly, early skin reaction with grade I seen in $63 \%$ of the patients, grade II skin reaction in $24 \%$, grade III skin reaction in $3 \%$ and no grade IV skin reaction seen in any patient. Our skin reaction results show none of the patients having any severe early or late radiation skin reaction, majority of the patients had early desquamation 44\%(22/50), 20\%(10/50) had dry desquamation, $8 \%(04 / 50)$ had grade IV skin reaction and grade I skin reaction(erythema) was seen in $28 \%(14 / 50)$.

Our complete local control rate was $56 \%(28 / 50)$ and complete nodal response rate was $52 \%(26 / 50)$ which were comparable with CC Wang et al study with the same treatment protocol with complete local rate for advanced T3 and T4 lesion 57\%, complete nodal response of $59 \%$ respectively. While our partial local control rate was 36\% $(18 / 50)$ and partial response rate was $40 \%(20 / 50)$ in patients.[24]

In our study, better tumour control was seen for Carcinoma Buccal Mucosa in $72.72 \%$ (16/22) patients followed by Gingivo-alveolar Carcinoma in $57.14 \%$ (8/14) patients. While one of each of Ca tongue and lower lip showed complete response rate of $4 \%$ and 3\% respectively. And this may be because of presentation of these cancers in far advanced stages with poor risk factors.

All of the patients were of poor risk factors with advanced T3 64\% (32/50) and stage T4 36\% (18/50). Even though the results are good as compared to conventional therapy for stage III and IV cancer of Oral Cavity and Oropharynx which ranged from 39\% and 51\% respectively (Table 5 and 9, Page No. 149 Willam T. Moss Radiation Oncology Rationale, Technique result).

\section{CONCLUSION}

Split-course accelerated hyperfractionated radiotherapy has a better outcome in terms of complete local control rate [56\% (28/50)] and complete nodal response rate [52\%(26/50)] as compared to conventional therapy for stage III and IV head and neck cancer. It is also tolerated well with low incidence of grade III (32\%) and IV (16\%) mucositis.

\section{REFERENCES}

[1] Machiels JP, Lambrecht M, Hanin FX, et al. Advances in the management of squamous cell carcinoma of the head and neck. F1000 Prime Rep 2014;6:44.
[2] Alam MS, Perween R, Siddiqui SA. Comparison of two different radiation fractionation schedules with concurrent chemotherapy in head and neck malignancy. Indian Journal of Cancer 2016;53(2): 265-9.

[3] Cognetti DM, Weber RS, Lai SY. Head and neck cancer: an evolving treatment paradigm. Cancer 2008;113(7 Suppl):1911-32.

[4] Parkin DM, Bray F, Ferlay J, et al. Global cancer statistics, 2002. CA Cancer J Clin 2005;55(2):74-108.

[5] Jemal A, Siegel R, Ward E, et al. Cancer statistics, 2007. CA Cancer J Clin 2007;57(1):43-66.

[6] Ries LAG, Melbert D, Krapcho M, et al. SEER cancer statistics review 1975-2004. National Cancer Institute. Available from: http://seer.cancer.gov/csr/1975_2004/

[7] Brizel DM, Albers ME, Fisher SR, et al. Hyperfractionated irradiation with or without concurrent chemotherapy for locally advanced head and neck cancer. New England Journal of Medicine 1998;338(25):1798-804.

[8] Nieder C, Baumann M. Re-irradiation: new frontiers. Springer 2017:17-34.

[9] Abdel-Wahab MM, Wolfson AH, Raub W, et al. The role of hyperfractionated re-irradiation in metastatic brain disease: a single institutional trial. Am J Clin Oncol 1997;20:158-60.

[10] Bauman GS, Sneed PK, Wara WM, et al. Re-irradiation of primary CNS tumors. Int J Radiat Oncol Biol Phys 1996;36(2):433-41.

[11] Bentzenh SM, Johansen LV, Overgaard J, et al. Clinical radiobiology of squamous cell carcinoma of the oropharynx. International Journal of Radiation Oncology Biology Physics 1991;20(6):1197-206.

[12] Hellevik T, Martinez-Zubiaurre I. Radiotherapy and the tumor stroma: the importance of dose and fractionation. Frontiers in oncology 2014;4:1.

[13] Bernier J, Hall EJ, Giaccia A. Radiation oncology: a century of achievements. Nat Rev Cancer 2004;4(9):737-47.

[14] Biswal BM, Ruzman N, Ahmad NM, et al. Split-Course radiotherapy in stage IV head \& neck cancer. The Malaysian journal of medical sciences 2000;7(1):54-9.

[15] Parkin DM, Pisani P, Ferlay J. Global cancer statics. CA Cancer J Clin 1999;49(1):33-64.

[16] Dowlatshahi M, Iganej S, Ciabatone A, et al. Uninterrupted moderately accelerated radiotherapy in the treatment of unresectable/advanced head and neck cancer: one institution's experience and a comparative review. Am J Clin Oncol 2000;23(2): 149-54.

[17] Marcial VA, Hanley J, Rotman M. Split-course radiation therapy of carcinoma of the tonsillar fossa: results of a prospective national collaborative clinical trial of the radiation oncology group (abstract). Int J Radiat Oncol Biol Phys 1978;4(suppl):17-8.

[18] Parsons JT, Bova FJ, Million RR. A re-evaluation of split-course technique for squamous cell carcinoma of the head and neck. Int J Radiat Oncol Biol Phys 1980;6(12):1645-52. 
[19] Million RR, Zimmerman RC. Evaluation of the university of Florida split-course technique for various head and neck squamous cell carcinomas. Cancer 1975;35(6):1533-6.

[20] Beitler JJ, Zhang Q, Fu KK, et al. RTOG 90-03: final report. International Journal of Radiation Oncology Biology Physics 2012;84(3):S6.

[21] Thames HD, Peters LT, Withers HR, et al. Accelerated fractionation vs hyperfractionation: rationales for several treatments per day. International Journal of Radiation Oncology Biology Physics 1983;9(2): 127-38.

[22] Saunders M, Dische S, Barrett A, et al. Continuous, hyperfractionated, accelerated radiotherapy (CHART) versus conventional radiotherapy in non-small-cell lung cancer: a randomised multicentre trial. The Lancet 1997;350(9072):161-5.
[23] Fu KK, Pajak TF, Trotti A, et al. A radiation therapy oncology group (RTOG) phase III randomized study to compare hyperfractionation and two variants of accelerated fractionation to standard fractionation radiotherapy for head and neck squamous cell carcinomas: first report of RTOG 9003. International Journal of Radiation Oncology Biology Physics 2000;48(1):7-16.

[24] Wang CC. Local control of oropharyngeal carcinoma after two accelerated hyperfractionation radiation therapy schemes. International Journal of Radiation Oncology Biology Physics 1988;14(6):1143-6. 